\title{
Distribution of the CCR5delta32 allele (gene variant CCR5) in Rondônia, Western Amazonian region, Brazil
}

\author{
Josileide Duarte de Farias ${ }^{1,2}$, Marlene Guimarães Santos ${ }^{1,2}$, Andonai Krauze de França ${ }^{2}$, Daniel Delani ${ }^{2}$, \\ Mauro Shugiro Tada ${ }^{3}$, Almeida Andrade $\mathrm{Casseb}^{2}$, Aguinaldo Luiz Simões ${ }^{4}$ and Vera Engracia ${ }^{1,2}$ \\ ${ }^{1}$ Laboratório de Genética Humana, Instituto de Pesquisas em Patologias Tropicais, Porto Velho, RO, Brazil. \\ ${ }^{2}$ Universidade Federal de Rondônia, Porto Velho, RO, Brazil. \\ ${ }^{3}$ Serviços em Saúde Pública, Centro de Pesquisa em Medicina Tropical, Porto Velho, RO, Brazil. \\ ${ }^{4}$ Departamento de Genética, Faculdade de Medicina de Ribeirão Preto, Ribeirão Preto, SP, Brazil.
}

\begin{abstract}
Since around 1723, on the occasion of its initial colonization by Europeans, Rondonia has received successive waves of immigrants. This has been further swelled by individuals from northeastern Brazil, who began entering at the beginning of the twentieth century. The ethnic composition varies across the state according to the various sites of settlement of each wave of immigrants. We analyzed the frequency of the CCR5 332 allele of the CCR5 chemokine receptor, which is considered a Caucasian marker, in five sample sets from the population. Four were collected in Porto Velho, the state capital and the site of several waves of migration. Of these, two, from the Hospital de Base were comprised of HB Mothers and HB Newborns presenting allele frequencies of $3.5 \%$ and $3.1 \%$, respectively, a third from the peri-urban neighborhoods of Candelária/Bate-Estaca (1.8\%), whereas a fourth, from the Research Center on Tropical Medicine/CEPEM ( $0.6 \%)$, was composed of malaria patients under treament. The fifth sample (3.4\%) came from the inland Quilombola village of Pedras Negras. Two homozygous individuals (CCR5 $\triangle 32 / C C R 5 \triangle 32)$ were detected among the HB Mother samples. The frequency of this allele was heterogeneous and higher where the European inflow was more pronounced. The presence of the allele in Pedras Negras revealed European miscegenation in a community largely comprising Quilombolas.
\end{abstract}

Key words: CCR5, CCR5 432 , Rondônia, genetic polymorphism, allele frequency.

Received: June 7, 2011; Accepted: September 30, 2011.

\section{Introduction}

In Brazil, the contribution of genes of Amerindian, African and European origin to the population has assumed various different patterns in the Amazonian Region, to the point that, in the State of Rondônia, migration became a significant factor in the diversification of ethnic composition. The initial colonization through a succession of emigrational waves was maintained, during the 1970's, when the capital, Porto Velho, and the nearby regions received numerous workers, natives of the southern and southeastern regions, as well as individuals descended from Italians, Germans and other nationalities, this intense gene flow giving rise to a tri-ethnic population pattern (Ferreira et al., 2002).

The CCR $5 \Delta 32$ allele appears to have originated quite recently (approximately 7,000 years ago) in northeastern

Send correspondence to Vera Engracia. Laboratório de Genética Humana, Instituto de Pesquisas em Patologias Tropicais, Porto Velho, Rua da Beira 7671, Rodovia BR 364, km 3.5, 76812-245 Porto Velho, RO, Brazil. E-mail: engracia.oliveira@uol.com.br.
Europe (Lidén et al., 2006). Although its frequency has now reached a relatively high level in Europeans, e.g., $16.3 \%$ in Finns and 15.8\% in Moravians, it is not present among African populations, and is only so at low levels in the Asian (Martinson et al., 1997). Hence, by application it is possible to evaluate the influence of the European population on the genetic constitution of others.

According to Passos and Picanço (1998), in Brazil, its distribution varies in accordance to geographical location and ethnicity, i.e., $3.5 \%$ in the urban population of southeastern Brazil and $0 \%$ in Amerindians. Imbalances in the geographical distribution of the CCR $5 \Delta 32$ allele might either enable certain populations to show better adaptive responses to a series of environmental threats (Galvani and Novembre, 2005) or, on the contrary, be a risk factor in the development of a number of infections (Vargas et al., 2009). According to Faure and Royer-Carenzi (2008), the distribution of this allele would depend on various genetic and/or environmental factors, such as the pathogen nature, thus resulting in an advantageous or disadvantageous relationship to the host. 
Other genetic polymorphisms that occur in the CCR5 gene have also been described, viz., A29S, L55Q and R60S, which may be associated with HIV-1 infection (Howard et al., 1999; Teixeira et al., 2009; Hütter and Ganepola, 2011). According to Sullivan et al. (2001), the presence of the CCR $5 \Delta 32$ allele in a population could possibly influence the epidemiological trends of HIV infection, since the prevalence of HIV/AIDS is higher in populations that present low CCR $5 \Delta 32$ allele frequency compared with those with a high frequency of homozygous or heterozygous individuals.

According to data from the Health Secretariat of Rondônia, there was a rise of $11.8 \%$ in the incidence of AIDS between 1997 (5.8\%) and 2009 (17.6\%), given a margin of 100,000 inhabitants. Consequently, the objective here was to determine CCR5 $\Delta 32$ allele frequency in certain localities with different settlement backgrounds. The presence of Caucasian genes was predicted to reflect the gene flow coming from historical migration waves.

\section{Materials and Methods}

\section{Populations and areas of study}

The study was carried out with samples collected in two regions of Rondonia, the city of Porto Velho (63⒌' $14^{\prime \prime} \mathrm{W}$; $08^{\circ} 45^{\prime} 43^{\prime \prime} \mathrm{S}$ ) and the rural village of Pedras Negras $\left(62^{\circ} 54^{\prime} \mathrm{O} ; 12^{\circ} 51^{\prime} \mathrm{S}\right)$. The first three were from Porto Velho, one from the city's riverine region and the remainder from other locations. The fourth subsample was collected in the rural region of the state in the village of Pedras Negras, situated in the Guapore River valley. A map of the region is presented in Figure 1.

\section{a. Samples from the region of Porto Velho}

HB: The HB samples, collected between March and April, 2005, at the maternity Hospital de Base (HB) Dr. Ary Pinheiro, the main public hospital in the State of Rondônia,

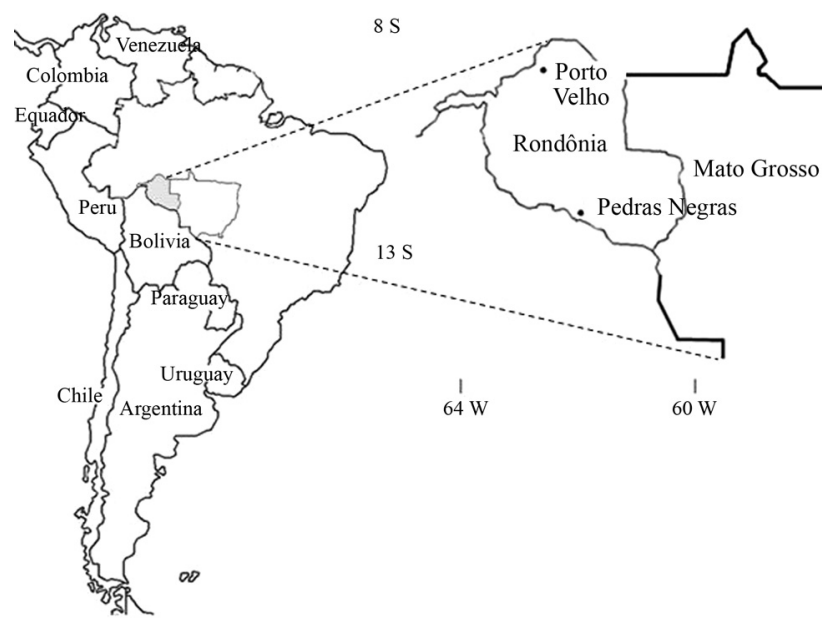

Figure 1 - Map of Brazil indicating the geographical location of the city of Porto Velho and that of the village of Pedras Negras. comprised 310 mothers (HB Mothers) and 305 newborns (HB Newborns). For statistical analysis, they were considered as two independent sub-samples. The mothers were from various locations in Porto Velho or the neighboring towns.

CBE: This sample, consisting of specimens stored in the Laboratory of Human Genetics of the Research Institute on Tropical Pathologies (IPEPATRO), had been collected during 2001 and 2002 by some of the authors and a group of physicians and paramedics of the Research Center on Tropical Medicine (CEPEM), linked to the Health Department of the State of Rondônia. The 111 individuals, from two riverine neighborhoods of Porto Velho, Candelária (83) and Bate-Estaca (28), were unrelated, and descended from Barbadian, European and Brazilian workers from the country's northeastern region, who had migrated to Porto Velho during the beginning of the twentieth century.

CEPEM: This sample was composed of 84 unrelated individuals from the general population of Porto Velho (diagnosis and treatment) in 2001 and 2003.

\section{b. Sample from the Guapore Valley region}

This subsample, composed of 29 unrelated individuals from the village of Pedras Negras, were descendants of the Quilombo, a traditional Afro-Brazilian community. Material collection was undertaken in 2002 by a group of researchers from IPEPATRO and physicians working for the State of Rondônia in the town of Costa Marques (near Pedras Negras).

\section{Blood collection}

After obtaining written consent, $5 \mathrm{~mL}$ of peripheral blood were collected in EDTA vacutainer tubes. In the case of newborns from the Base Hospital, blood was collected from the umbilical cord, transported in refrigerated containers to the Laboratory of Human Genetics of the IPEPATRO, and processed within $10 \mathrm{~h}$ of leukocyte collection. All the samples were stored in aliquots at $-20^{\circ}$ Cuntil further use.

\section{DNA extraction}

Genomic DNA was extracted from leukocytes using $300 \mu \mathrm{L}$ of peripheral blood according to the protocol described by Higuchi (1989).

\section{Detection of the CCR5 polymorphism}

CCR5 genotyping was performed by PCR using specific primers (CCR5Forward: 5' - GGTCTTCATTACAC CTGC - 3' and CCR5Reverse: 5' - AGGATTCCCGAG TAGCAGATG - 3') and the protocol described by Chies and Hutz (2003). PCR reactions were prepared in a final volume of $25 \mu \mathrm{L}$ as follows: $3 \mu \mathrm{L}$ of genomic DNA, $2.5 \mu \mathrm{L}$ of 10X PCR buffer (200 mM Tris-HCl, pH 8.4, $500 \mathrm{mM}$ $\mathrm{KCl}), 2.5 \mu \mathrm{L}$ of a $200 \mu \mathrm{M}$ dNTP mix, $1.5 \mu \mathrm{L}$ of $50 \mathrm{mM}$ $\mathrm{MgCl}_{2}, 0.14 \mu \mathrm{L}$ of each primer at $0.25 \mu \mathrm{M}$ and $0.15 \mu \mathrm{L}$ of 
Taq DNA polymerase $(5 \mathrm{U} / \mu \mathrm{L}$; Invitrogen Corporation, San Diego, CA, USA). The conditions for thermocycling were: 1 cycle of 5 min at $94{ }^{\circ} \mathrm{C}, 30$ cycles of $1 \mathrm{~min}$ at $94^{\circ} \mathrm{C}$, $1 \mathrm{~min}$ at $63{ }^{\circ} \mathrm{C}$ and $1 \mathrm{~min}$ at $72{ }^{\circ} \mathrm{C}$, followed by a $10 \mathrm{~min}$ final extension at $72{ }^{\circ} \mathrm{C}$ (Eppendorf Mastercycler gradient, Eppendorf AG, Hamburg, Germany). The PCR amplification products were subjected to electrophoresis on a $10 \%$ polyacrylamide gel $\left(100 \mathrm{~V}, 1 \mathrm{~h} 30^{\prime}\right)$ and stained with $10 \%$ silver nitrate. The CCR5/CCR5 genotype was detected as a single band of 137 base pairs (bp), the CCR5/CCR5 332 heterozygous genotype as a band of $137 \mathrm{bp}$ plus another of $105 \mathrm{bp}$, and the CCR $5 \Delta 32 / \mathrm{CCR} 5 \Delta 32$ homozygous genotype as a single band of $105 \mathrm{bp}$.

\section{Statistical analysis}

Statistical analysis was performed using the GENEPOP 4.0 (Rousset, 2008) and SPSS 19.0 Programs. Allele frequencies were obtained by maximum likelihood, and adherence to Hardy-Weinberg equilibrium tested by the chi-square test. $95 \%$ confidence intervals were calculated. A first attempt to estimate the degree of racial mixing in the present study-population, undertaken with only two of the sample groups, viz., parturient women (HB Mothers) and newborns (HB Newborns), was obtained using the ADMIX95 software developed by Chakraborty (1985). The genetic systems, previously validated in the same two sample groups, and their associated parental frequencies, were CCR5, CYP2E1 (cytochrome P450, subfamily IIE, polypeptide 1), GSTP1 (glutathione S-transferase class Pi) and ACP1 (acid phosphatase of low molecular weight)

\section{Ethic procedures}

This research was approved by the Brazilian Council of Research Ethics (CONEP, Number 13356).

\section{Results and Discussion}

The distribution frequencies of the CCR $5 \Delta 32$ allele in the samples from Porto Velho and Pedras Negras, two towns located in the State of Rondônia (Table 1), were heterogeneous and reflected the settlement history of Rondô- nia (Pinto, 1993), with higher frequencies in locales where the European flow was more intense (Teixeira and Ribeiro da Fonseca, 1998).

Ethnicity in the two samples from the Hospital de Base was predominantly African (64 and 65\% for the HB Mothers and HB Newborns, respectively). In these samples, the $\Delta 32$ allele frequency was $0.035 \pm 0.153$ $\left(\mathrm{p}=0.0477 ; \chi^{2}=7.136\right)$ among mothers and $0.031 \pm 0.030$ $\left(p>0.05 ; \chi^{2}=0.315\right)$ among newborns. Although the European contribution was higher in the filial than the maternal generation $(17 \%$ vs. $5.9 \%$ Caucasian genotypes, respectively), two women homozygous for $\Delta 32$ were detected among the mothers. The first Brazilian report of individuals homozygous for the CCR $5 \Delta 32$ allele was provided by Grimaldi et al. (2002), who, while investigating the occurrence of this allele in various ethnic groups from various regions, observed that its frequency varied according to ethnicity. Anthropogenetic data, collected in the interviews prior to blood collection, indicated that the HB sample was composed of individuals, who were either natives of other regions of the country or of other northern states $(24.5 \%$ of the sample). Approximately $7.94 \%$ of the individuals in the study were from the northeastern region. Contributions from the other regions (midwestern, southern and southeastern) were lower.

The lowest CCR5 $\triangle 32$ allele frequency of $0.0006 \pm 0.000\left(p>0.05 ; \chi^{2}=0.003\right)$ was observed in the Porto Velho CEPEM subsample, with only one individual bearer. The Porto Velho riverine subsample (represented in this study by CBE) was comprised of individuals from the first emigration movements, mainly Barbadians and individuals from the northeast. While CCR $5 \Delta 32$ allele frequency in this population was $0.018 \pm 0.013(\mathrm{p}>0.05$; $\chi^{2}=0.037$ ), the allele itself was only observed in the heterozygous state. This low frequency could be expected, given the background of settlement by Negroid populations and miscegenation with the Amerindian people, present during the first colonization movements along the Madeira River (Ferreira, 1987). Pedras Negras, located in the southern

Table 1 - Genotypic distribution and gene frequencies of the CCR5 allele in different population samples of Porto Velho and of the village of Pedras Negras - Rondonia, Brazil.

\begin{tabular}{|c|c|c|c|c|c|c|c|}
\hline \multirow[t]{2}{*}{ Samples } & \multicolumn{7}{|c|}{ Alleles and frequency } \\
\hline & ${ }^{2} \mathrm{WT} / \mathrm{WT}$ & $\mathrm{WT} / \Delta 32$ & $\Delta 32 / \Delta 32$ & $\Delta 32$ allele & $\chi^{2}$ & (p-value) & Standard deviation \\
\hline${ }^{\mathrm{HB}}$ Mothers & 290 & 18 & 02 & 0.035 & 7.136 & 0.0477 & 0.153 \\
\hline${ }^{\mathrm{HB}}$ Newborns & 286 & 19 & 0 & 0.031 & 0.315 & $\mathrm{P}>0.05$ & 0.030 \\
\hline${ }^{1} \mathrm{CBE}$ & 107 & 04 & 0 & 0.018 & 0.037 & $\mathrm{P}>0.05$ & 0.013 \\
\hline Pedras Negras & 27 & 02 & 0 & 0.034 & 0.037 & $\mathrm{P}>0.05$ & 0.018 \\
\hline CEPEM & 83 & 01 & 0 & 0.006 & 0.003 & $\mathrm{P}>0.05$ & 0.000 \\
\hline Total & 793 & 44 & 02 & 0.025 & - & - & - \\
\hline
\end{tabular}

${ }^{1}$ Villages of Candelária and Bate Estaca. ${ }^{2}$ WT: Wild type. 
Guapore Valley (midwestern Rondônia), was originally populated by the descendants of slaves who had escaped from gold mining operations in the former capital of the State of Mato Grosso, between 1734 and 1835, thus having arrived in the Guapore Valley at least 200 years ago. This is the only region in Rondônia with a population that was originally Quilombolan (Teixeira MAD, 2004, PhD Thesis, Universidade Federal do Pará, Belém). The current inhabitants are mostly descendants of the union between Negroids and Caucasians, although the population also features a maternal native-Amerindian heritage. The observed frequency of the $\Delta 32$ allele in this group was $0.034 \pm 0.018(\mathrm{p}>0.05$; $\left.\chi^{2}=0.037\right)$.

Allele frequencies, similar to those found in the Rondonian samples, have been detected in other Brazilian regions, i.e., $0.6 \%$ in Cepem, $0.7 \%$ in African-Brazilian populations from Pará (Carvalhaes et al., 2004), 0.9 and 1.0\% in Bahia (Carvalho et al., 2004), 1.8\% in Candelária and Bate-Estaca and $1.9 \%$ and $2.0 \%$ in African-Brazilian individuals in Rio de Janeiro (Chies and Hutz, 2003) and Paraná (Boldt et al., 2009), respectively. Among $\mathrm{HIV}^{+}$subjects, frequencies ranged from $2.1 \%$ in Rio de Janeiro (Teixeira et al., 2009) to $2.4 \%$ in Rio Grande do Sul (Vieira et al., 2011), 2.6\% in a miscegenated population in Bahia (Grimaldi et al., 2002) and 3.8\% in São Paulo (Rigato et al., 2008). Hünemeier et al. (2005) found frequencies of 2.0 and 3.0\% in Amerindian populations from south Brazil. Boldt et al. (2009) observed frequencies of at least $0.9 \%$ in Amerindians from the state of Paraná. The presence of the $\Delta 32$ allele in Amerindian populations is an indication of historical European miscegenation. The frequencies detected in our samples $(3.1 \%$ in the HB Newborns, 3.4\% among the Quilombolas of Pedras Negras and 3.5\% of the HB Mothers sample) were similar to those found in an urban population of Belém (3.0\%; Carvalhaes et al., 2004), an urban population of Ribeirão Preto, São Paulo (3.5\%) and a mixed population in Alegrete, RS (3.8\%). However, our frequencies were lower than the $4.4 \%$ observed in the Euro-Brazilian population of Porto Alegre, and the 4.7\% and $5.8 \%$ of patients with sickle-cell anemia, thus of African descent, from Recife and Porto Alegre (RS), respectively (Chies and Hutz, 2003). Brazilian populations described as Afro-Brazilian presented allele frequencies of $5.6 \%$ in the state of Bahia (Carvalho et al., 2004) and 8.0\% in the state of Rio Grande do Sul. The populations described as Euro-Brazilians generally presented the highest frequencies in the southern states: $6.5 \%$ in Joinville, State of Santa Catarina; $6.5 \%$ in Alegrete, State of Rio Grande do Sul; and 9.3\% in the State of Paraná (Grimaldi et al., 2002; Vargas et al., 2006; Boldt et al., 2009, respectively).

Sullivan et al., (2001) noted that the heterozygous presence of the mutant CCR5 allele can influence HIV epidemiological trends within a population, possibly through limiting the epidemic by reducing the likelihood of viral transmission by infected heterozygous individuals. In
2009, out of 150 HIV tests administered in the Vale do Guaporé, 80 proved to be positive. According to the state's health department, the northern region of Brazil (which includes Rondônia) exhibited a 39.6\% increase in AIDS cases from 2002 to 2006. This high regional incidence incited us to analyze the $\Delta 32$ allele, which is of European origin (Faure and Royer-Carenzi, 2008), in a population of Quilombolan descendents, although without investigating the relationship between CCR5 $\triangle 32$ and AIDS. Notwithstanding, future studies in this region should thus address this issue, given the high incidence of HIV infection.

In conclusion, the European heritage of the individuals comprising the current population of Rondônia was reflected in our observation of the CCR5 $\Delta 32$ allele in the Quilombolan population of the Guapore Valley, the ethnically heterogeneous mothers from the Hospital de Base of Porto Velho, and individuals from Candelária and BateEstaca, where the current population is descended from $\mathrm{Ne}$ groid immigrants and native Amerindians.

\section{Acknowledgments}

We would like to thank Dr. Amado Ahamad Rahhal for authorizing collection within the Hospital de Base of Porto Velho, Rondônia, as well as MSc Joana D'Arc Neves Costa for access to CEPEM samples of malaria patients. We would also like to acknowledge all of the subjects who agreed to take part in the study. This work was supported by IPEPATRO, Fiocruz and FNS.

\section{References}

Boldt ABW, Culpi L, Tsuneto LT, Souza IR, Kun JFJ and PetzlErler ML (2009) Analysis of the CCR5 gene coding region diversity in five South American populations reveals two new non-synonymous alleles in Amerindian and high CCR5 $\Delta 32$ frequency in Euro-Brazilians. Genet Mol Biol 32:12-14.

Carvalhaes FAPL, Cardoso GL, Hamoy IG and Guerreiro JF (2004) Distribution of CCR5- 332 , CCR2-64I, SDF1-3'A mutations in populations from the Brazilian Amazon region. Hum Biol 76:643-646.

Carvalho MWP, Leboute APM, Oliveira SF, Sousa SMB, Klautau-Guimarães MN and Simões AL (2004) CCR5D32 mutation in three Brazilian populations of predominantly SubSaharan African ancestry. Genet Mol Biol 27:231-325.

Chakraborty R (1985) A note on the calculation of random RP and its sampling variance. Hum Biol 57:713-717.

Chies JAB and Hutz MH (2003) High frequency of the CCR5delta32 variant among individuals from an admixed Brazilian population with sickle cell anemia. Braz J Med Biol Res 36:71-75.

Faure E and Royer-Carenzi M (2008) Is the European spatial distribution of the HIV-1-resistant CCR5-Delta32 allele formed by a breakdown of the pathocenosis due to the historical Roman expansion? Infect Genet Evol 8:864-874.

Ferreira MR (1987) A Ferrovia do Diabo. Editora Melhoramentos, São Paulo, 408 pp. 
Ferreira RGM, Moura MM, Engracia V, Pagotto RC, Alves FP, Camargo LMA, Pereira da Silva LH, Camargo EP, Beiguelman B and Krieger H (2002) Ethnic admixture composition of two western Amazonian populations. Hum Biol 74:607-613.

Galvani AP and Novembre J (2005) The evolutionary history of the CCR5-Delta32 HIV-resistance mutation. Microbes Infect 7:302-309.

Grimaldi R, Shindo N, Acosta AX, Dourado I, Brites C, de Melo Carvalho O, Brito I, Bou-Habib DC and Galvao-Castro B (2002) Prevalence of the CCR5 32 mutation in Brazilian populations and cell susceptibility to HIV-1 infection. Hum Genet 111:102-104.

Higuchi R (1989) Simple and rapid preparation of samples for PCR. In: Erlich HA (ed) PCR Technology: Principles and Applications for DNA Amplification. Stockton Press, New York, pp 31-38.

Howard OM, Shirakawa AK, Turpin JA, Maynard A, Tobin GJ, Carrington M, Oppenheim JJ and Dean M (1999) Naturally occurring CCR5 extracellular and transmembrane domain variants affect HIV-1 Co-receptor and ligand binding function. J Biol Chem 274:16228-16234.

Hünemeier T, Neves AG, Nornberg I, Hill K, Hurtado AM, Carnese FR, Goicoechea AS, Hutz MH, Salzano FM and Chies JA (2005) T-cell and chemokine receptor variation in South Amerindian populations. Am J Hum Biol 17:515-518.

Hütter G and Ganepola S (2011) The CCR5-delta32 polymorphism as a model to study host adaptation against infectious diseases and to develop new treatment strategies. Exp Biol Med 236:938-943.

Lidén K, Linderholm A and Götherström A (2006) Pushing it back. Dating the CCR5-D32 bp deletion to the Mesolithic in Sweden and its implications for the Meso/Neo transition. Doc Praehist 33:29-37.

Martinson JJ, Chapman NH, Rees DC, Liu YT and Clegg JB (1997) Global distribution of the CCR5 gene 32-basepair deletion. Nat Genet 16:100-103.

Passos GAS and Picanço VP (1998) Frequency of the $\triangle$ CCR 5 deletion allele in the urban Brazilian population. Immun Lett 61:205-207.

Pinto EP (1993) Rondônia, Evolução Histórica: Criação do Território Federal de Guaporé, Fator de Intergração Nacional. Editora Expressão e Cultura, Rio de Janeiro, 216 pp.
Rigato PO, Hong MA, Casseb J, Ueda M, de Castro I, Benard G and Duarte AJ (2008) Better CD4 ${ }^{+}$T cell recovery in Brazilian HIV-infected individuals under HAART due to cumulative carriage of SDF-1-3'A, CCR2-V64I, CCR5-D32 and CCR5-promoter 59029A/G polymorphisms. Curr HIV Res 6:466-473.

Rousset F (2008) GENEPOP'007: A complete re-implementation of the genepop software for Windows and Linux. Mol Ecol Resour 8:103-106.

Sullivan AD, Wigginton J and Kirschner D (2001) The coreceptor mutation CCR532 influences the dynamics of HIV epidemics and is selected for by HIV. Proc Natl Acad Sci USA 98:10214-10219.

Teixeira MAD and Ribeiro da Fonseca D (1998) História Regional (Rondônia). ABG Gráfica Editora, Porto Velho, $241 \mathrm{pp}$.

Teixeira SLM, Bastos FI, Hacker MA and Morgado MG (2009) Distribution of CCR5 genotypes and HLA ClassI B alleles in HIV-1 infected and uninfected injecting drug users from Rio de Janeiro, Brazil. Infect Genet Evol 9:638-642.

Vargas AE, Marreno AR, Salzano FM, Bortolini MC and Chies JAB (2006) Frequency of CCR532 in Brazilian populations. Braz J Med Biol Res 39:321-325.

Vargas AE, Cechim G, Correa JF, Gomes PA, Macedo GS, Medeiros RM, Perotoni G, Rauber R, Villodre ES and Chies JAB (2009) Pros and cons of a missing chemokine receptor comments on "Is the European spatial distribution of the HIV-1-resistant CCR5-D32 allele formed by a breakdown of the pathocenosis due to the historical Roman expansion?' by Eric Faure and Manuela Royer-Carenzi (2008). Infect Genet Evol 9:387-389.

Vieira VC, Barral MF, Mendoza-Sassi RA, Silveira JM, Soares MA and Martinez AM (2011) The effect of combined polymorphisms in chemokines and chemokine receptors on the clinical course of HIV-1 infection in a Brazilian population. Mem Inst Oswaldo Cruz 106:408-414.

Associate Editor: Mara Hutz

License information: This is an open-access article distributed under the terms of the Creative Commons Attribution License, which permits unrestricted use, distribution, and reproduction in any medium, provided the original work is properly cited. 